\title{
The Logic of Urban Squatting
}

Submitted for publication in International Journal of Urban and Regional Research 15-082011 (Pruijt, Hans (2013) The Logic of Urban Squatting. International Journal of Urban and Regional Research, 37(1), 19-45, DOI: 10.1111/j.1468-2427.2012.01116.x)

Hans Pruijt

pruijt@fsw.eur.nl

Erasmus Universiteit Rotterdam

Faculty of Social Sciences - Sociology

Burgemeester Oudlaan 50

3062 PA Rotterdam

The Netherlands

\section{Abstract}

Existing frameworks tend to break when applied to the analysis of urban squatting. Five basic configurations, combinations of features that fit together well and are therefore effective, are discussed in this paper. In the case of squatting, configurations differ with respect to the characteristics of the people involved, type of buildings, framing, demands made by activists, mobilization and organization patterns. Each configuration also entails specific problems. Deprivation based squatting involves poor people who are distressed because of severe housing deprivation. In squatting as an alternative housing strategy people organize squatting to meet their own housing needs. Entrepreneurial squatting offers opportunities for setting up nearly any kind of establishment, without the need for large resources nor the risk of getting bogged down in bureaucracy. Conservational squatting involves squatting as a tactic used in the preservation of a cityscape or landscape against efficiency-driven planned transformation. Political squatting is a field of action for those who are engaged in anti-systemic politics.

Keywords:

Squatting, social movements, housing

Urban squatting is living in - or using otherwise - a dwelling without the consent of the owner. Squatters take buildings with the intention of relatively long-term use. Urban squatting can be distinguished from the squatting of vacant land. Occupancy without legal title has always existed, but this paper focuses on squatting that is organized or at least supported and/or inspired by a social movement. Such inspiration comes from an activist promoted master frame that is based on empowerment and enables "cognitive liberation" (Nepstad 1997: 471) by letting people see empty buildings as opportunities and imagine that collective support for occupying those buildings can be organized.

In Amsterdam in 1966 activists from the anarchist Provo Movement launched such a frame in the form of a "White Houses Plan". A "working group" announced that they would distribute lists of empty houses and would paint doors and doorjambs of empty homes white. The "Woningbureau (Housing Bureau) de Kraker" was established in 
1969. The name reflects the fact that Dutch squatters started to use the special term "krakers" to designate people who aim at turning their squats into long-term homes (Van Tijen, 2008). In Berlin, the term "instandbesetzen", a conflation of "instandsetzen" (renovating) and besetzen (occupying) was coined.

Contemporary urban squatting in Europe can be seen as flowing forth from organized squatting in the 1960s, but squatting is not dependent on a climate of countercultural upheaval. The fact that it was done on a large scale shortly after WWII (Friend, 1980; Johnstone, 2000) testifies to this.

The literature offers widely divergent interpretations, which conveys the impression that it is an elusive movement. Various authors portrey the squatters' movement as a collective actor pursuing a certain goal. To Corr (1999: 3), the movement's goal is "to redistribute economic resources according to a more egalitarian and efficient pattern", for Wates (1980) it is to address housing issues, while Mamadouh (1992) sees it as a means to assert a romantic small-is-beautiful vision against the dominant functionalistic practice of city planning. Kallenberg (2001) classifies squatting among the utopian struggles, which would imply that the goal of the squatters' movement is a better society. Katz and Mayer (1985) suggest that the goal is to enable and further self-help. Thus between authors, the goals ascribed differ widely. Adding to the variety, there are also authors who see squatting not as goal-directed but as a movement driven by a need for counter cultural and/or political expression (Lowe, 1986; Van Noort, 1988). Assessments diverge too in this strand of the literature. Clarke, Hall, Jefferson and Roberts (1976: 58) see squatting as an example of a middle class counter-culture and Wietsma, Vonk and van der Burght (1982: 4) as a "way to shape one's life and one's living environment in a way that breaks with imposed norms and laws". For McKay (1998) it represents a manifestation of Do It Yourself culture. Della Porta and Rucht (1995: 121-123) classify the squatters' movement as a "left-libertarian" movement, while, in sharp contrast with this, Katsiaficas (1997: 115) pictures squatters as progenitors to, and later a wing of, the "international Autonomen", a more or less Leninist strand of political activism. Martinez (2007: 381) views the squatters' movement as a "rhizomatic" or "immediatist" movement, while Adilkno (1994) sees it as post-modern, postideological, and mass media-influenced. And some emphasize that people squat to lead an "extreme way of life" (Anon, 1998: 20).

None of these assessments is completely incorrect; overviews of squatting show a great variety of squatting projects within countries and also within cities (Wates and Wolmar, 1980; Wakefield, 1995; Birke, 2009; Birke and Holmsted, 2007;

Kaulingfreks et al., 2009; van Gemert, Siegel, Visser, Dadusc and Brouwers, 2009), any of the interpretations fits somewhere, some time, to some extent and in some way. This paper is an attempt to contribute to a comparative analysis of squatting that takes the diversity as the starting point, rather than departing from one interpretation that would be spot-on in some cases, but that would work as a very artificial model in other cases. The core of the paper is the development of a typology of urban squatting, specifically designed as an alternative for the often-made distinction between squatting as a way of meeting a housing need and squatting as a way of satisfying a need for counter cultural and/or political expression (Lowe, 1986) that has already been shown to be incorrect by Kinghan (1977) and Van der Pennen, Bertram et al. (1983). They found that meeting unmet housing needs was an important motive for all squatters.

The theoretical and conceptual base is as follows. For the general framework, I have drawn on contingency theory. McAdam and Scott (2005) have introduced 
contingency theory in the context of social movement studies, but so far it has seen little use in social movement research. Contingency theory explains diversity as a result of adaptation to optimize efficiency and effectiveness. In the case of squatting, awarding an important role to efficiency and effectiveness is appropriate because squatting hinges on a transformation process: unused buildings are transformed into safe, acceptable or comfortable homes, or spaces that are used in other ways and infused with life. Mintzberg (1983) conceptualized adaptation as congruence, i.e. achieving fit with the environment, and configuration, achieving internal consistency. In Mintzberg's (1983) terminology, which I adopt, configurations are internally consistent combinations of features that correspond logically to specific environment characteristics.

For selecting the dimensions of description I have drawn on New Social Movement theory, because this approach is inherently comparative and because the squatters' movement has been counted among the New Social Movements (van Loo, Snel and van Steenbergen, 1984; Ziere, 1992). The concept of New Social Movements implies a comparison with old or classic movements. New Social Movements are said to have a network structure and an informal, unstable and enthusiastic model of organization (Calhoun, 1993) which offers participants the flexibility to be active without a fixed commitment (Tarrow, 1994). Participants are primarily middle class (Pichardo 1997). Kriesi (1989) identifies the key actors in a New Social Movement as belonging to a specific section of the middle class: cultural and social service providers. Thes actors oppose threats to their autonomy posed by technocrats and bureaucrats and would like to see a society with little managerial control. We can infer that when such activists apply their idea of an ideal society to their own movement, this will result in attempts to build network structures with horizontal decision making. In terms of goals, New Social Movements are said to differ from other movements because they focus not just on political goals but also on cultural objectives, on enacting a cultural identity (Melucci, 1989; Polletta and Jasper, 2001). Finally, the literature on New Social Movements suggests that activists tend to be active in more than one of the movements that make up this movement family (Kriesi et al., 1995). These various characteristics said to set New Social Movements apart from other movements can be translated into dimensions of description: activists' goal, class, organization form and cultural and political embedding.

A contrasting literature exists that emphasizes demands and the agency of activists who design frames to organize experience by simplifying and condensing aspects of 'the world out there', to find resonance and to guide action (Benford, 2000).

Therefore, I included demands and framing among the dimensions of description. Beyond these dimensions derived from social movement theory, I included the type of buildings as a dimension that is highly specific to squatting.

The empirical base is the squatting experience in the Netherlands, the UK, Germany and Italy. The Netherlands can be seen as a real-life laboratory that offered activists ample opportunity to explore what is possible in squatting. This is because affordable housing shortages were persistent, while between 1971 and 2010 it was possible to squat without breaking the law. All types of squatting are present in the 45 years of Dutch squatting history, but some possibilities were less developed in the Netherlands than in other countries. For this reason, I have included the UK, Italy and Germany. The UK was the scene of systematic campaigns to organize squatting for poor people (Bailey, 1973, Wates 1980), and the practice of creating and running large scale squatted social centers was well developed in Italy (Mudu, 2004). Germany (Geronimo, 1995) and Italy (Welschen, 1996) offered cases in which activists 
involved themselves in squatting for ulterior political motives. Together with a similar case in the Netherlands, this provided a base for analyzing political squatting.

Squatting in the Netherlands was studied using the extensive descriptive literature and by means of interviews, examination of archives and systematic collection of documentation produced in the movement. An important source of information was the complete set of issues of the main squatters' periodical (Kraakkrant, 1976-1981) and its successors (Laatste Waarschuwing, 1981, Bluf!, 1981-1988, NN, 1988-1995, Ravage, 1996-2002). Direct observations at meetings, parties, actions including lobbying and other events were made from 1977-1985 and 2003-2010. Squatting in the UK, Germany and Italy was mainly studied using available literature, although visits to squats in these countries were made.

The resulting typology consists of five basic configurations of squatting.

Configurations are combinations of features that are logically consistent and fit to the environment, and can therefore be expected to be efficient and effective.

The five configurations are:

1 Deprivation based squatting

2 Squatting as an alternative housing strategy

3 Entrepreneurial squatting

4 Conservational squatting

5 Political squatting

Below I will derive the various squatting configurations, placing an emphasis on developing the logic. A complete, systematic overview of the dimensions of the configurations is given in Table 1 .

Note that the restrictive definition of squatting as intended relatively long term use excludes the use of buildings as crash pads, as well as demonstrative occupations. ${ }^{1}$

Conceptually, squatting projects are the units of analysis. A squatting project can only belong to a single configuration, but it is possible for squatting projects belonging to different configurations to share the same building.

\section{Deprivation based squatting}

The oldest configuration may be called deprivation based squatting. This configuration involves poor, working class people who are distressed due to severe housing deprivation. Severe housing deprivation means more than having a need for housing; it implies that such people have virtually no other options than living in a homeless shelter. A further restriction is that such individuals have a specific status that allows them to be seen as deserving accommodation. Generally, there is a broadly shared opinion about who does and who does not deserve to be housed. The norms that govern this are time- and place-specific. An example, in England, in the 1960s and 1970s only married people with children tended to be eligible for being defined as homeless (Wates, 1980). ${ }^{2}$ In the 1960 in the Netherlands, being a homeless married couple without children was sufficient to be classified as deserving (Duivenvoorden, 2000). 


\begin{tabular}{|c|c|c|c|c|c|}
\hline & $\begin{array}{l}\text { Deprivation based } \\
\text { squatting }\end{array}$ & $\begin{array}{l}\text { Squatting as an alternative } \\
\text { housing strategy }\end{array}$ & $\begin{array}{l}\text { Entrepreneurial } \\
\text { squatting }\end{array}$ & Conservational squatting & Political squatting \\
\hline $\begin{array}{l}\text { Activists' } \\
\text { goals }\end{array}$ & $\begin{array}{l}\text { Providing housing for } \\
\text { needy people. }\end{array}$ & $\begin{array}{l}\text { Creating housing for } \\
\text { themselves, while adding to } \\
\text { the affordable housing stock. }\end{array}$ & $\begin{array}{l}\text { Setting up an } \\
\text { establishment. }\end{array}$ & $\begin{array}{l}\text { Preserving a cityscape or } \\
\text { landscape. }\end{array}$ & Building up counter-power to the state. \\
\hline Class & $\begin{array}{l}\text { Lower class squatters } \\
\text { supported by middle } \\
\text { class activists. }\end{array}$ & $\begin{array}{l}\text { Middle class (but not } \\
\text { exclusively). }\end{array}$ & $\begin{array}{l}\text { Middle class (but not } \\
\text { exclusively). }\end{array}$ & $\begin{array}{l}\text { Middle class (but not } \\
\text { exclusively). }\end{array}$ & Middle class (but not exclusively). \\
\hline Organization & $\begin{array}{l}\text { Top-down, division } \\
\text { between activists and } \\
\text { beneficiaries. }\end{array}$ & Horizontal. & Mixed. & Mixed. & Top-down. \\
\hline $\begin{array}{l}\text { Type of } \\
\text { buildings }\end{array}$ & $\begin{array}{l}\text { Regular low-income } \\
\text { housing stock } \\
\text { inexcusably left empty. }\end{array}$ & $\begin{array}{l}\text { Buildings that are either too } \\
\text { bad or too good to be rented } \\
\text { out as low income housing. }\end{array}$ & Non-housing spaces. & $\begin{array}{l}\text { Buildings emptied because } \\
\text { of a planned change in land } \\
\text { use. }\end{array}$ & Few restrictions. \\
\hline Demands & $\begin{array}{l}\text { Modest. } \\
\text { Temporary housing or } \\
\text { alternative } \\
\text { accommodation. } \\
\text { (Better) place on } \\
\text { waiting list. } \\
\end{array}$ & Being left alone. & Being left alone. & Reversal of planning. & $\begin{array}{l}\text { Confrontation is the essence, demands } \\
\text { are at most supplementary. }\end{array}$ \\
\hline Framing & $\begin{array}{l}\text { Clear message: } \\
\text { insensitive bureaucrats } \\
\text { ignore needs of } \\
\text { homeless people. }\end{array}$ & $\begin{array}{l}\text { Focus on action, framing not } \\
\text { very important. }\end{array}$ & $\begin{array}{l}\text { Valuable role of the } \\
\text { establishment in the } \\
\text { community. }\end{array}$ & $\begin{array}{l}\text { Against technocratic } \\
\text { planning and destruction of } \\
\text { the environment. }\end{array}$ & Depicting social-democrats as traitors. \\
\hline $\begin{array}{l}\text { Cultural and } \\
\text { political } \\
\text { embedding }\end{array}$ & $\begin{array}{l}\text { Sometimes a tenuous } \\
\text { link with radical } \\
\text { politics. }\end{array}$ & $\begin{array}{l}\text { Embedded in counter culture, } \\
\text { ties with other movements. }\end{array}$ & $\begin{array}{l}\text { Embedded in counter } \\
\text { culture, ties with other } \\
\text { movements. }\end{array}$ & $\begin{array}{l}\text { Embedded in counter } \\
\text { culture, ties with other } \\
\text { movements. }\end{array}$ & $\begin{array}{l}\text { Links with Marxist organizations or } \\
\text { movements. }\end{array}$ \\
\hline Outcomes & Cooptation likely. & Repression and legalization. & $\begin{array}{l}\text { Repression and } \\
\text { legalization. }\end{array}$ & Sometimes concessions won. & $\begin{array}{l}\text { Makes squatting a more prominent target } \\
\text { for repression. May also - in the short } \\
\text { term - help squatters win concessions. }\end{array}$ \\
\hline $\begin{array}{l}\text { Specific } \\
\text { problems }\end{array}$ & $\begin{array}{l}\text { Does not work for } \\
\text { people whose housing } \\
\text { needs are not widely } \\
\text { acknowledged. Top } \\
\text { down organization } \\
\text { limits movement } \\
\text { spread and increases } \\
\text { vulnerability. }\end{array}$ & Social control. & $\begin{array}{l}\text { Preserving identity } \\
\text { after legalization. } \\
\text { Trade-off between } \\
\text { alternative identity and } \\
\text { wide appeal. }\end{array}$ & None. & $\begin{array}{l}\text { Conflicts with squatters in other } \\
\text { configurations. }\end{array}$ \\
\hline
\end{tabular}

Table 1 Configurations of squatting 
A key aspect of this configuration is that it is tightly organized squatting. A prototypical example of deprivation based squatting is the "family squatters movement" in the UK in the late 1960s. Activists who were determined to organize housing for homeless families started this in 1969. They did this by squatting and by distributing housing that local authorities, put under pressure by the squatting actions, turned over to them. These were houses that had been removed from the regular rental stock. A Family Squatting Advisory Service was established to organize this distribution, which had one paid staff member (Bailey, 1973).

A different form is mass squatting. An example is a 1945-46 UK wave of squatting in ex-military camps, initiated by a committee of ex-servicemen (Friend, 1980). ${ }^{3}$ Largescale deprivation based squatting has not been confined to the 1940s. Groups of home-seekers occupied flats in Italy in the late 1960s (Welschen, 1996: 82-86). Starting in the early 1970s, the specific housing predicaments of newly arrived migrants gave rise to deprivation based squatting. An example: in 1974, a Surinamese action committee in Amsterdam led the squatting of around one hundred apartments in the Bijlmermeer by newly arrived immigrants from Surinam (Van Diepen and Bruijn-Muller, 1977), and in Frankfurt, in the early 1970s, there were also activists who occupied buildings in order to provide housing for immigrants (Grundmann et al., 1981: 48). In 1998, in Bologna, the "The Committee without Frontiers" and Rifondazione Comunista organized squatting for North African immigrants (Fekete, 1998). Contemporary examples of deprivation based squatting projects exist. In 2010, the squatters' association Zwart-Rode Vrijheid (Black-Red Freedom), set up to provide housing for people with various personal troubles, was thriving in the Dutch town of Etten-Leur.

An organizational pattern that has a clear distinction between activists and squatters fits well within this configuration of deprivation based squatting. The activists open up buildings for the squatters and support them. This division of roles fits into the overall logic of the configuration, because it clearly puts the squatters in the position of people who need to be helped. It also implies some protection against possible accusations of queue jumping: the activists do not take the initiative to organize squatting out of a selfish motive; they do it to help others. A social distinction between the squatters and the activists, when the activists are of middle class origin, is functional here.

In deprivation based squatting, it is possible to take advantage of the perception that the squatters are needy and deserving, by choosing empty buildings belonging to owners who have a (moral) obligation to house the needy and therefore would be embarrassed to be seen evicting squatters. Among such owners are the state and the Church. Ideally, the target for squatting is regular housing stock, left empty for inexplicable or inexcusable reasons. The better the condition of the buildings, the more embarrassing it is that the owners have left them empty.

The central demand in this configuration does not involve structural change, but instead focuses on helping the squatters to obtain (temporary) leases or alternative accommodation. This type of squatting can be variously embedded in socialist, humanitarian and/or religious activism; one may say that it constitutes a protest against government inefficiency and insensitivity.

Careful framing can help win supporters and put pressure on the authorities. In this configuration, the framing is straightforward. The needs of homeless families, who ideally have become distressed for reasons beyond their control, i.e. working poor, are pitted against the insensitivity of bureaucrats and politicians. Squatters claim respectability, which enables the public to identify with them. When evictions take 
place, a shock effect is produced by the uncivilized or insensitive behavior of the authorities or their agents. Bailey (1973) describes how bailiffs, by violently evicting families from squatted council owned houses in London, created a public relations disaster for the city officials who had hired them.

A more radical political demand that is sometimes made is to requisition unused private property. An example is the campaign undertaken by a Brighton group who called themselves the "Vigilantes". In 1945 they occupied houses that were only rented during the holiday season. This resulted in a new law that made requisitioning possible. It was only implemented in Labour-run cities (Friend, 1980).

In the UK, limitations of this configuration in terms of the demands that can be raised became apparent when in 1946, 1500 people squatted investor-owned apartments in London, with Communists playing an organizing and supporting role. In contrast to the generally positive coverage of the government owned ex-military camp occupations, much of the press reporting was hostile as the right of individual owners to do with their property what they pleased was attacked. Evictions and punishment ensued (Friend, 1980: 116; Johnstone, 2000).

Deprivation based squatting is susceptible to cooptation, i.e. transformation into a form that is useful to state officials (Pruijt, 2003). A salient example of cooptation can be found in the history of squatting in the UK. There, some squatters' organizations were transformed into management offices that rented out short-life public sector accommodation. This was called "licensed squatting" (Bailey, 1973; Pettitt, 1980). The deals with local authorities, that made this possible, required squatters' organizations to give up organizing squatting. Lowe (1986: 148) called licensing "a classic example of the cooptation of a critical social movement."

A specific problem of this configuration of squatting is that it has little to offer to people whom authorities or the public do not recognize as having a genuine housing need (ASS, 1996: 31). Home seekers who have problems beyond homelessness, or people whose lifestyle ostensibly deviates from the mainstream, will have difficulty meeting the respectability requirement.

A further problem, to the extent that there is a division of roles between activists and squatters, is that the continuity of squatting depends on a small core of activists who may shift interest or burn out. It is also very important that squatters in this configuration have, beyond homelessness, no other serious problems such as substance abuse, dealing or stealing, sexual or domestic violence. If not, additional risks of repression loom, and activists that support squatters who have multiple problems run the risk of turning into unpaid social workers (Grundmann, Schulz, Becker, Emig and Pospisi, 1981: 49).

\section{Squatting as an alternative housing strategy}

A newer configuration of squatting could be called squatting as an alternative housing strategy, i.e. squatting as a more or less viable alternative to(sub)renting. Compared to the previous configuration, it is less restrictive. Squatting as an alternative housing strategy opened up squatting for people of middle class origin. Examples are students or downwardly mobile individuals who have chosen to dedicate themselves to activities that bring few financial rewards, e.g. visual artists and musicians. Squatting as an alternative housing strategy is wide open to home-seekers outside of the category of people that are, at that specific time, seen as urgently in need of housing, for example because they are unmarried, have no children, are young or are welltrained. 
Coming from a desperate situation is not required, it is open to squatters who were not previously homeless, but lived in a rented room or a student dormitory, and want to move into an apartment. Squatting as an alternative housing strategy can be attractive for people who want to live in a group and cannot find legal accommodation that makes this possible and for radical DiY enthusiasts, who would rather create housing for themselves by investing a lot of time in it than working long hours in a job to pay a high rent (Moan, 1980). Just living rent-free without investing a lot of time is also possible, either by being lucky enough to find a place that does not need much work or by putting up with primitive circumstances.

Although it opened up squatting for people of middle class origin, squatting as an alternative housing strategy is open to vulnerable, poor people. For the latter, it has advantages above deprivation based squatting, because it involves less or no stigmatization. ${ }^{4}$

That we are dealing with a configuration that is distinct from deprivation based squatting is illustrated by the reflections of Pettitt (1980: 122) who decided to move into a squat herself, after a period of time during which she had dedicated herself to the London Family Squatting Movement and helping others to squat:

"Somehow we accepted the reasoning which implied that if one wasn't in a 'family', then one didn't need a permanent home of one's own. My own train of thought went something like this: 'Me? But I've got a degree! How can I justify needing to squat? I don't look deserving enough. It'll make squatting look silly if people like me do it, with no cockney accents and no children."'

In this configuration, the basic desire is not to get help but to be left alone and in peace. Demands are mainly tactical tools toward the goal of being left alone. Because demands are not very important, as compared to deprivation based squatting, in this configuration there are no strict requirements on framing, although explaining the action to neighbors and to the public may be helpful. Squatters do not present themselves as unlucky souls who require assistance. The disempowering effect of being (self-) labeled as deprived is avoided. Squatters do not stigmatize themselves as losers, instead they derive pride from a self-created housing solution.

The fact that squatters do not to assert a place among the deprived and needy, and are not presented as such, gives rise to potential moral and legitimacy problems when they squat homes that are intended to be let to low-income people. In the Netherlands, this pertains to social housing that is distributed under state control. These moral and legitimacy problems do not occur with types of buildings that allow squatting to be seen as adding to the affordable housing stock, rather than fighting for a share of it. Suitable buildings include commercial spaces that were never intended to be used for housing. Large buildings that do not contain apartments but are suitable for communal living fit also well in this configuration. The same holds true for rental units that have been taken off the market because of demolition plans. Housing which is (far) below rentable standard is suitable, as are empty homes that are so expensive that they can never be counted as being part of the affordable housing stock.

When spaces that meet the criteria outlined above are chosen, squatting becomes a two-edged sword: squatters help themselves outside the perimeter of the existing affordable housing stock and at the same time, by removing themselves from the waiting queues for authority-allocated housing, indirectly help other low-income home seekers.

Compared to deprivation based squatting, squatting as an alternative housing strategy 
involves less division between activists/organizers on the one hand, and squatters on the other hand. There is more self-organization in autonomous teams, and less topdown organizing. "Less" is not "none", the phenomenon of informal leadership exists although it is sometimes contested; in the Netherlands, there was a long standing debate about "union bosses" in which the rise of leaders was criticized. Logically, self-organization is a well-fitting concept in a configuration in which squatters are not defined as needy.

Some authors, for example Lowe (1986) see this type of squatting as a way of satisfying a need for counter cultural and/or political expression, however this obscures the fact that meeting housing needs tends to be an important motive for all squatters regardless of whether they are subculturally oriented (Kinghan, 1977; Van der Pennen, Bertram et al., 1983). Indeed, many squatters live in a squat just as they would in a rented place, at least in the Netherlands. Thus it seems more accurate to note that squatting as an alternative housing strategy can be embedded in counter culture and politics. This entails the following.

Apart from accommodation, squatting offers the opportunity to adapt the housing situation to a chosen lifestyle. Punks may, for example, chose to live together with punks, feminists may start a women's building. Experimenting with communal living is easy. Squatted commercial spaces can be converted in creative ways. An example: in Amsterdam, an artist built a small wooden house inside a large space in the former Handelsblad building (also known as NRC building). Squatting offers ample possibilities for creative interior and exterior decoration.

Empowerment is an element in counterculture and countercultural politics. It results from the acts of establishing squats. Squatting breaks through a dependent attitude toward both the state and the market, at least in the area of housing. Squatters distance themselves from the bureaucratically regulated way of home making. They gain selfconfidence because they take care of their own housing needs, by occupying a building and making it inhabitable. They break the power exerted over them by city planning, waiting lists and the norms of private property rights which require that homeless people remain quietly homeless while around them houses stand empty. One of the appeals of squatting is that it promises an immediate tangible result in the form of a realized squat. This is different from political participation through formal channels. In these channels, a division of labor, hierarchy and inevitable compromising make it difficult for participants to trace the result of their invested energies.

Some squatters involve themselves deeper in squatting. They form a network or squatter scene. Spending time in the company of other squatters is rewarding because of the shared experience and because it offers the relaxation of not having to defend the principles of squatting. The non-squatting environment tends to label squatters as different, which in itself helps forge a group identity. Know-how on technical matters, such as dealing with owners, locks, windows, broken floors, plumbing, heating, electricity and how to obtain relevant supplies is rapidly disseminated.

Ideology is only loosely coupled to practice. All squatting is highly practical, but in contrast to deprivation based squatting, demands to authorities are relatively unimportant, obviating the need for a clear consistent explanation of actions. This allows for considerable freedom when creating an ideology around squatting as an alternative housing strategy. Examples are instant anarchism, suddenly discovered with little influence from the anarchist tradition, or ideologies with an anti-capitalist or anti-property rights theme. Another possibility is emphasizing continuity with mainstream values such as self-reliance, community and livability. The non- 
centralized structure further promotes ideological diversity.

Within the squatters' scene, movement building can take place. We can distinguish different forms of organization in the squatting movement:

- General cooperation and mutual assistance. This means that squatters make themselves available to other squatters or potential squatters to provide advice, help them out of problems or organize a group that assists when a new building is squatted. Neighbors help each other and cooperate.

- Internal organization in large buildings. In large buildings a lot has to be arranged collectively, for example the energy supply. Commonly there will be regular house meetings.

- Associations. The establishment of squatter groups is very important, especially in districts in which mainly separate apartments or small apartment buildings are squatted. Squatter's groups have meetings and some collective money. Squatters' groups and collectives that occupy large buildings can start to work together, thereby forming a wider movement.

- Structured networks without division of labor: for example, a telephone tree for mobilizing support in case of an eviction threat.

- Organization based on a voluntary division of labor: the creation of small institutions that provide services to squatters or those interested in squatting. Examples: information services for potential squatters that sometimes maintain lists of empty properties and provide advice to make squatting accessible and more likely to be successful; collectives that write squatting manuals; squatters' media such as newsletters, magazines, radio and television stations, websites, online forums and mailing lists. In Amsterdam, a bureau exists that investigates property speculators: the SPOK, Speculatie Onderzoeks Collectief (Speculation Investigation Collective.) Art centers such as Tacheles in Berlin, described by Holm and Kuhn (2011: 7) as spaces created to "help squatters achieve self-realization", book shops and public kitchens have a function as part of the infrastructure of the movement.

- Organized campaigns. A goal can for example be squatting a large property. Squatters develop a strategy, mobilize people, assign tasks, cooperate during the action and evaluate afterwards.

- Overarching citywide, regional or national organizing. Collective threats, such as proposed anti-squatting legislation especially stimulate squatters to call overarching meetings and organize protests in their cities, to coordinate national protests and set up committees.

- Coalitions with tenants, for example to improve living conditions in the neighborhood.

Squatters' movements can overlap with other movements in protest waves. Squatters' movements are part of a "left-libertarian social movement family" (della Porta and Rucht, 1995: 121-123), including for example the ecology movement and the new peace movement. The movements within this family have organizational overlaps. Squatters can take the notion of applying direct action, and their experience with it, to sundry troubled spots in society. Historic examples from the Netherlands in the 1980s of squatters branching out into other fields are: blockading the road leading to the nuclear power plant in Dodewaard and blockade actions against the transportation of nuclear waste on its way to be dumped in the sea. Squatters blockaded the entrances to the Shell laboratory complex in Amsterdam as part of anti-apartheid protests. Direct action tactics, pioneered in the squatters' movement, have also been transferred to anti-militaristic protest. Military command bunkers and one military office were 
raided and documents detailing contingency plans in case of a State of National Emergency stolen, displayed and published. A similar action occurred at a building used by a covert police observation unit. A raid to disrupt an extreme-rightwing party meeting in a hotel ended in a devastating fire caused by a smoke-bomb. Squatters have also played a major role in urban protests, for example against the construction of the new town hall in Amsterdam, occupying the site with an "Anti-City Circus", or derailing Amsterdam's campaign to attract the Olympic Games, by harassing the International Olympic Committee members assembled in Lausanne. In 1999, squatters were active in the logistics part of a tour, the "Inter Continental Caravan", of 500 Indian peasants though Europe who wanted to show how Western policies affect their lives.

Squatting as an alternative housing strategy can lead to various outcomes. A key payoff of squatting is that it enables people to satisfy their immediate housing needs by direct action, i.e. creating (often temporary) homes. According to a 1981 study (Van der Raad, 1981) Amsterdam housed around 9,000 squatters. Duivenvoorden (2000) estimated that in the Netherlands as a whole, between 1965 and 1999, 50.000 people lived in squats at one time or another. Also of interest is the longevity of the squats. There is a relation with quality because a longer life expectancy for a squat makes it possible to invest more in repairs, construction and maintenance. Wates (1980) estimated an average life span of several months, but less than one year, for squats in the UK. I estimate an average squat life span of several years in the 1980s, strongly declining after 1994, for Amsterdam.

Some squats have become permanent homes through legalization. The Municipality of Amsterdam bought two hundred of the buildings that were occupied by squatters (Duivenvoorden, 2000: 323), thereby legalizing them. This fitted in an already formulated government policy to supply housing to young people. The role of pressure caused by resistance against evictions can not be discounted. Officials then turned most of these buildings over to established housing associations that concluded lease contracts with individual squatters (Draaisma and Hoogstraten, 1983). This allowed squatters to consolidate what they had achieved. The flip side is that legalization takes away the alternative edge (Bussemaker, 1986). Because legalization entails repairs and sometimes conversion to the level required by the building code, it tends to increase cost, putting an end to the situation that money matters little. In this situation, some people with very low incomes will have to leave, or they become dependent on some arrangement by which they can substitute work for "rent". Nevertheless, in the Netherlands few, if any, opportunities for legalization have been missed. In Berlin, however, there was a sizeable proportion of squatters that refused to negotiate for legalization.

Squatting can cause a housing shortage issue to gain prominence on the political agenda. The media can play an independent role in this. This occurred in the case of the Vetterstraat in Amsterdam, 1965. The squatters were just trying to help themselves, but a newspaper printed the following comment:

"A big riot might be useful. We risk forgetting that in this country there is a disgraceful housing shortage. The burden of this is passed almost exclusively onto a varying group of young people. The housing situation is a sick spot in our society. But we almost made this illness invisible". (Trouw, 7 jan. 1965)

In the Netherlands, a major effect of squatting is that it has put the housing shortage on the political agenda. In 1978 in Amsterdam, a twenty-year-old could expect to wait 
more than seven years to be allocated a distribution apartment. The minimum age to be put on the waiting list was twenty-five. From that point, one had to wait a few years to get to the top of the queue. In 2011, in Amsterdam it still takes years of patience to eventually obtain an apartment in the "social sector", i.e. state controlled housing for citizens with low and medium incomes.

Sometimes squatters explain their actions as a protest against a shortage of affordable housing and refer to this when mobilizing public support. An example is the "Groote Keijser" in Amsterdam in 1979-1980, a case in which squatters refused to give up a row of occupied canal houses (Keizersgracht 242-252). They explained their stand as a protest against a housing shortage that affected 50,000 home seekers in a population of 600,000 .

In the monumental inner city of Amsterdam, squatting led to the establishment of new "weak" functions such as housing for young people, often living in groups, weak in the sense that these functions tend to lose out in the competition for land because there is little financial profit to be made from it. In some cases these functions are protected through legalization (Duivenvoorden, 2000: 323; Breek and de Graad, 2001).

A specific problem of squatting as an alternative housing strategy is that two of the strengths of this configuration, that many people can do it and that the organizational structure is decentralized, simultaneously represent weaknesses because they limit the possibilities for squatters to exert social control over their fellow squatters. This is relevant because of the precarious legitimacy of squatting. To illustrate this: in a 2006/2007 survey ( $N=2173)$ in the Netherlands, 36.8 percent of respondents agreed with the statement "Squatting an empty building should always be forbidden". 42.5 percent disagreed. ${ }^{5}$ Cases can occur in which squatters damage the building and/or display behaviour that disturbs the neighbors, contributing to a media backlash.

\section{Entrepreneurial squatting: social centers, free spaces, breeding places}

Squatting offers opportunities for setting up nearly any kind of establishment, without the need for large resources nor the risk of becoming mired in bureaucracy. Examples of such projects are neighborhood centers, squatters' bars that provide an infrastructure for squatting as an alternative housing strategy and raise money for actions and charity projects, artists' work spaces, practice facilities for bands, women's houses, restaurants, print shops, theaters and movie theaters, tool lending services, alternative schools, daycare centers, party spaces, art galleries, book- and info shops, spiritual centers, give-away shops (shops in which everything is free), food shops, saunas, workshops, e.g. for bicycle repair or car or boat restoration, environmental or third world oriented projects or social projects such as a shelter for people in distress or an advisory service with language training for migrants. In Italy entrepreneurial squatting projects tend to be routinely labeled as social centers. Activists in other countries such as Spain and the UK have adopted this label. In 1998, 150 squatted self-managed social centers in Italy offered opportunities to enjoy and develop social life in a non-commodified environment (Maggio, 1998: 234). Mudu, (2004) counted 200 social centers in Italy.

Ruggiero (2000: 170) stated that important functions of social centers rest in reducing loneliness and repairing the gap in the opportunities for identity building caused by the decline of large workplaces, unions and political parties. They also allow unemployed people to engage in productive activity such as organizing concerts and 
producing and selling cd's, magazines and T-shirts. Social centers maintain strong links with the alternative music scene. Some see this as meaningful work with a welcome degree of self-control, for others it represents self-exploitation (Wright, 2000: 128). The centers provide contacts, access to resources and opportunities for acquiring skills that are relevant in the job market (Ruggiero, 2000: 182-183). Often social centers or free spaces are established together with housing. In the Netherlands, squatters promoted the combination of functions in one building as an asset in its own right (Duivenvoorden, 2000: 252-253).

The scale and the type of buildings can vary. Examples range from one small storefront to a large commercial center, a military complex, warehouse, shipyard or an entire village.

Because of the broad range of entrepreneurial squatting, it is hard to make general statements about the class origin of participants. In the Netherlands, there were many artists as well as others who had at least a few years of university training. Consorzio Aaster (1996: 29) reports on a survey among 1395 users of social centers in Milan that includes the level of education as a variable. 36.1 per cent had at least a few years in university, 20.1 percent did not have more than the compulsory three years of secondary education. Mudu (2004: 926) indicated that visitors of social centers in the northern and central parts of Italy tend to be mixed to in terms of social class, while social centers tend to involve "people living on the fringes of society".

In terms of organization, there is variation, of only because the scale varies so much. A fairly common characteristic is informal organization. The status as squats limits external obligations. Because of this, their is relatively little need for formal organization, as long as there is no legalization. Mudu (2004) observes that the informal structure of squatting projects allows for continued progress even when there is a high turnover of participants.

In terms of factors that promote mobilization, unemployment is important. When substantial youth unemployment exists, such as existed in the Netherlands in the early 1980s, and in Spain since 2005, there are large numbers of resourceful young people looking for opportunities to engage in meaningful activities. Initiatives often appeal to specific age or ethnic groups. For example, an Italian survey of social center visitors $(\mathrm{N}=1395)$ showed that only 4.9 per cent were older than 35 years (Consorzio Aaster, 1996: 23). However, some centers, such as the Leoncavallo in Milan, have multiple spaces and activities that attract different age groups. And in the UK, the Exodus collective in Luton, started by organizing raves and branched out into squatting, became known for cutting across ethnic barriers (Malyon, 1998).

Entrepreneurial squatting projects are practical and are therefore not very dependent on sophisticated ideological framing. At least at the start, whipping up a lot of public support tends to be unnecessary. This changes when there is an eviction threat, which can prompt activists to demand that city administrators and politicians act to help save the project. When the need for framing arises, it is logical to advance a functionalist frame, emphasizing the valuable role of the project in the community, for example as a breeding place for the creative class (Florida, 2002; Romano, 1998; Uitermark, 2004; Pruijt, 2004).

As far as countercultural and political embeddedness in this configuration are concerned, there are two issues that are regularly debated.

The first issue is whether legalization results in the loss of the oppositional edge. An in-depth study on squatted "free spaces" in Amsterdam describes commonly occurring effects of legalization as: a loss of links to various societal structures, of ties with other free spaces, and a decline of dynamism and political engagement (Breek and de 
Graad, 2001: 77).

There are projects where the oppositional identity did not whither away, rather it died abruptly with legalization, such as the Groote Keijser, the already mentioned canal houses Keizersgracht 242-252. In other legalized squats it eroded gradually, e.g. the NRC-complex, Tetterode in Amsterdam. Sometimes a role in alternative culture has remained, such as in the case of the Poortgebouw in Rotterdam, which has remained a venue for alternative music. An important factor is the level of control that occupants can retain after legalization. Often legalization involves a housing non-profit organization taking control of the building and turning the squatters into individual tenants. In other cases, the ex-squatters remain in control as a collective (Breek and de Graad, 2001: 50).

Legalization is not the only explanation of the erosion of the Dutch squatters' scene's political edge. There has been a general decline in left-wing protest in the Netherlands since 1980, which was the apex of a protest wave. After 1980, resources for social movements in the Netherlands also declined, as it became both easier and more necessary for young people to find paid employment. The state also began to put pressure on students to complete their studies swiftly.

Some projects did retain an oppositional edge after legalization, such as the Mehringhof in Berlin, and Vrankrijk in Amsterdam. Vrankrijk was bought by its squatters. ${ }^{6}$ Additionally, it is worth noting that various legalized projects, such as Kulturzentrum Lagerhaus in Bremen or the Fabrik in Berlin never had an oppositional identity; from the beginning they focused on (alternative) culture.

The second discussion is whether it is possible to escape from the trade-off between, on the one hand, choosing to assume a counter-cultural/political identity and because of this only attracting members of a highly exclusive "scene", for instance vegan anarchists, or on the other hand, choosing to attract a wide range of people at the expense of becoming culturally mainstream and non-political.

Marco (2000: 14), who was active in the Eurodusnie collective in Leiden in the Netherlands criticized the Dutch squatter scene for being exclusive, and contrasted it to the large number of social centers in Italy, which he describes as the central gathering places for the "anti-capitalistic part of the population" while also appealing to a wide variety of people. Many social centers solve the dilemma by offering space for a broad range of activities. Attracting a large audience, the Leoncavallo in Milan, for example, gets 100.000 visitors per year, places a burden on activists. They may see their ideologically inspired engagement slide into cleaning up the mess after a consumerist crowd.

Managing the social centers entails walking a narrow line between "ghetto mentality" and "possible normalization as social enterprises" (Wright, 2000: 132). Perhaps predictably, some criticized the social centers for having become commercial enterprises. Several social centers got together to draw up a plan, the Charter of Milan, to leave behind self-chosen isolation, confrontations with the police and "prejudice-ridden, anti-institutional discourse" and instead to develop a "more subtle infiltration of local institutions, a dialog that is not subservient but attains a new quality of antagonistic practice" (Klein, 2001; Maffeis, 2002: 134). Membretti (2007) speaks of flexible institutionalization.

Some representatives of social centers tried to counter the threat posed by the Berlusconi ascendancy by, successfully, running for local office (Klein, 2001). Most of the visitors come to the centers for their social contacts and for concerts and art (Ruggiero, 2000). However, the Social Centers are also "social and cultural hubs" in a network that supports mobilization against, for instance, capitalist globalization 
(Klein, 2001). They Italian social centers have spawned an innovation in the protest repertoire, the "Tute Bianche": a block of demonstrators dressed in white overalls symbolizing invisibility or ghostliness as a result of post-Fordist restructuring (Azzellini, 2002), later called "Disobbedienti", i.e. the "disobedient" (Mudu, 2004). Some centers are more politically oriented and some are more oriented toward (counter)culture. Tensions along this distinction also exist within centers. In addition to this, there are differences between autonomistic and anarchistic centers (Wright, 2000).

Entrepreneurial squatting has a wide array of possible outcomes. Projects can develop into institutions that have a long life span. As an example, the Vrijplaats

Koppenhingsteeg in Leiden, the Netherlands lasted forty years as a squat before it was evicted in 2010, and plans for resurrection in another location exist. Most long-lasting initiatives acquired a legal status, such as the squatters' bar Molli Chaoot in Amsterdam that is in existence since 1979, and Amsterdam's anarchist bookshop Fort van Sjakoo, that was squatted in 1977.

In the Dutch town of Utrecht, the main venue for pop concerts, Tivoli, with 300.000 visitors per year, was opened up in 1980 by punk music-loving squatters. In Amsterdam, the Paradiso pop music club was started by a squatting action in 1967. In Italy, major elements of the cultural landscape, such as the Forte Prenestino in Rome and the Leoncavallo in Milan are the products of entrepreneurial squatting. Leoncavallo, which started in the 1970s, obtained a long life by adopting the strategy to squat another building after eviction and to continue using the same name. Leoncavallo has been evicted and reopened in other buildings several times. A few firms got started in squatted premises. In 1981, the collective De Spruitjes (The Sprouts) started selling vegetables in de Paleisstraat in Amsterdam, close to the Royal Palace. By establishing their shop in a freshly legalized squat they could defy the economic logic that bans greengrocers from central locations, and continued to do so for 18 years. Bier \& Co, a specialty beer importer with more than 35 employees in 2011, started in the early 1980s in several squatted buildings. It was a cooperative before it was changed into a regular private company. In 1983 the brewery 't IJ, producer of biological beers, started in a squat on the bank of the IJ river in Amsterdam.

That the many artists' workspaces created in squatted buildings contributed to the favorable climate for the arts in Amsterdam was acknowledged by the municipal authorities: the City set up a bureau dedicated to the preservation and creation of "breeding places" to ensure the continuous supply of affordable space for artists. An outcome of entrepreneurial squatting is the buildup of experience that can be used in a different context. An example: in Amsterdam, an organization, Urban Resort, was created to make unused office and commercial buildings available at low cost to people who are starting out in the cultural or creative sector. One of their projects was the building that was left behind by the newspaper Volkskrant. Urban Resort's managing director Jaap Draaisma drew on his experience gained in the large Weijers squat, that was opened in 1981, that included housing, a restaurant, evening shop, a squatters' bar and an espresso café, and concert facilities, and was in the process of acquiring many more initiatives when it was evicted in 1984.

\section{Conservational squatting}

The fourth configuration, conservational squatting, involves squatting as a tactic used in the preservation of a cityscape or landscape. The goal is to prevent a 
transformation, in many cases a planned transformation, and to promote a development in a different direction. That such opportunities arise is caused by the mechanism that impending changes in land use result in vacant buildings. Squatting can increase resistance against land use change because the hot spots of the change those places where original inhabitants and users have already been displaced become populated again. Opportunities can be historic buildings that are standing empty awaiting demolition. Entire neighborhoods that that were planned to be cleared, or at least partially cleared, have also invited conservational squatting alongside other types of squatting. Examples are:

- The Tolmers Square neighborhood in Camden, London, in the early 1970s, where houses were to be replaced by office blocks.

- The Nieuwmarkt neighborhood in Amsterdam, also in the early 1970s, that was planned to be cut through by an urban motorway built in a corridor cleared for subway construction, and lined by office blocks as well as to be the site for a new hotel.

- Kreuzberg in Berlin. In Kreuzberg in 1979, the community action group "SO 36" occupied an empty fire station to prevent its demolition. The activists proceeded to occupy houses that were slated for razing, because they wanted to preserve both useable housing stock and the structure of the neighborhood.

- Friedrichshain in Berlin, 1990. Activists exhorted people to squat empty houses in the Mainzer Strasse to prevent destruction. This project involved 11 houses and 250 occupants (Holm and Kuhn, 2011).

Conservational squatting can also be undertaken to preserve the social function of a given building in the face of gentrification, for example low income housing that the owner wants to convert to market rate condominiums, with another term gentrification.

For a movement aiming to preserve a landscape of cityscape from being destroyed by the construction of infrastructure, squatting buildings in critical locations is one of the tactics that can be employed. Here, the buildings themselves are not very important, the objective is being in the way of the planned infrastructure. Examples are in UK, the No M11 Link Road campaign in the 1990s and in the Netherlands, the Betuwe Railway (1998-99). In such cases, squatters have the advantage of being immune to the standard NIMBY reproach, because they move into the area precisely because of the opportunity to contribute to the protection of the environment or the neighborhood, they can hardly be seen as NIMBYs.

The actors in conservational squatting tend to be "middle class interventionists" (Wates, 1976: 127) such as students or professionals who move into the area (cf. Bosma et al., 1984). ${ }^{7}$ The "middle class interventionists" tend to be young people with a special interest along with a housing need. In the Tolmers Square neighborhood, the first "proper" squatters were three architecture students (Wates, 1976: 160). They learned about the neighborhood and its problems when they did a case study as part of their degree program. The students discovered that there had been no inhabitant participation in the planning process and that the Council was only interested in the land, not in the inhabitants and their fate following redevelopment (Wates, 1976: 120). Their recommendations amounted to a plea for piecemeal redevelopment and renovation of as many buildings as possible instead of demolition. In a meeting that they set up with inhabitants, the Tolmers Village Association was created, in the daily management of which the student squatters played an important role. In the Nieuwmarkt neighborhood in Amsterdam, at least two of the initiators and central activists in the resistance against the planned transformation had prior activist 
involvement in spatial planning issues (Bosma et al., 1984). In 2000, environmentalists were among the activists who squatted the military fortress Pannerden in the Netherland, that had fallen into disrepair after its last use in 1940. Their idea was to prevent further decay, and move against possible redevelopment as a hotel. The squatters created homes, a museum, an visual artists' workspace and cultural activities and conducted monthly tours in the fortress.

Conservational squatting can also develop from squatting as an alternative housing strategy, when the squatted building is threatened to be demolished and when the occupants see opportunities for restoration. An example is a row of six houses in the Nieuwelaan in Delft, built in 1912, that was squatted in 1981. In 1995, the squatters presented a plan for a complete renovation.

Another possibility to start conservational squatting is to take over the stick from tenants who are resisting a planned transformation. An example is the resistance which started in 1975 against a planned parking garage in the Dutch town of Nijmegen, in the Piersonstraat. In 1980 the tenants' possibilities to thwart the scheme by legal action were exhausted, and the city had been successful in removing tenants by offering rehousing and financial compensation. One of the leaders of the tenant's protests approached the Nijmegen squatters' group to start taking over houses directly when they would be vacated (Van Wakeren, 1998; Bruls, 2006). The squatters called a mass protest and built street barricades in an attempt to prevent eviction and demolition.

Because conservational squatting is dependent on support from regular inhabitants, and can involve cooperation with tenants and other interested parties, it is logical that activists try to control who will squat available empty houses. In the Tolmers Square Neigborhood, there was an "informal screening system" for prospective squatters (Wates, 1976: 161). In Amsterdam's Nieuwmarkt neighborhood, activists set up a group that distributed houses that would be squatted. To be accepted, prospective squatters had to meet criteria such as being prepared to stay to the end i.e. the eviction and be ready to fight. The activists backed this up by establishing a scheme in which the squatters would collectively pay for necessary repairs, which made squatting houses that were in an exceptionally bad condition a more reasonable proposal, and by running a technical service center where various construction tools could be borrowed. They also made a commitment to arrange for re-housing after a possible eviction.

Core activists execized control in the neighborhood. Drug addicts were asked to leave. Bosma et al. (1984) quotes a squatter who recalled that one of the leaders did not allow him to paint the outside woodwork of his house in "hippie colors", he had to use a traditional canal house green.

Activists using conservational squatting in a neighborhood planning struggle are likely to to be faced with two types of conflict, as both the Tolmers Square and the Nieuwmarkt cases bear out. One is a conflict of interest between the preservationists and inhabitants who want to move out of the neighborhood anyhow and are planning to benefit from a re-housing scheme when their home is demolished. The second conflict is one of lifestyle; squatters can antagonize long-standing residents. Noise disturbances can exacerbate this.

A key ingredient of conservational squatting is the demand that planners change their course. For this reason, careful framing is important. It involves making planners, investors, developers, municipal decision makers etc. accountable and showing that the building or neighborhood is worth preserving. If applicable, squatters can seek to demonstrate the historic value of their squat. A classic example is a house at Achter 
Clarenburg 2, in Utrecht. The City bought it in 1969, planning to demolish it to make way for a new road. Students squatted it in 1971. One of them, a history student, discovered features hidden behind a modern facade and clutter that showed that the house was built around 1330. Alerted by this discovery, the central government's Monument Preservation Service scrambled to get it listed (Van den Berg, 2007). In Rotterdam, one of the city's last farmhouses was ready for demolition when it was squatted in 2005. The squatters presented plans that combined preserving the farmhouse as a historic building (Oostrom, 2010), celebrating Dutch rural traditions, ecological farming and hosting cultural activities.

The fact that squatting is sometimes seen as destructive, and it has happened that buildings were thrashed by squatters, can be a reason for squatters to explain that it can contribute to conservational efforts. For example, activists in the Nieuwmarkt neighborhood reported in a newsletter about the squatter conversion of commercial buildings on the Zwanenburgwal as follows:

"The block is squatted and converted by the occupants themselves at their own expense, with an enormous effort. Gas, electricity and water has been installed, toilets, heating, walls etc. made. While the municipality has not in decades done anything here, this is the first complex in the Nieuwmarkt where existing buildings have been converted into affordable housing. At this moment around 100 people live in 55 apartments. In the complex, already four children have been born." (Aktiegroep Nieuwmarkt, 1977: 11, continued on 13).

In an architecture, housing and urban planning magazine, Bijlsma et al. (1974: 13) promoted squatting as an important tool for citizens who want to help conserve their city and neighborhood. ${ }^{8}$ They stated that squatting is the way to prevent property developers, investors or the state from getting rid of unwanted houses by tricks such as making holes in the roof or letting the door stand open to attract drug users or "sleeping bag tourists" in the hope that they will destroy it or cause it to burn down. The authors add that a neighborhood that looks run down attracts investors, which is a reason for activists to make sure that squatted housed look good.

The squatters who lived in Fort Pannerden made it clear to the public that they had a rule not to apply paint or drill holes in the structure.

In terms of outcomes, squatting can be a successful means to save buildings. The already mentioned medieval house in Utrecht was restored, and of the original squatters, one couple was still living in the house forty years later. In Delft, the renovation of the Nieuwelaan houses that were squatted in 1981 finally started in 2004. In 2006, Fort Pannerden's squatters were summoned to leave. The squatters refused because there was not yet a definitive plan for renovation and because they suspected that the fortress would remain empty. It took the police, aided by the army who sent men and equipment including three bridge-laying tanks, two days for the eviction (Visser, 2006). Three weeks later, squatters retook the fortress. This time, instead of an eviction an agreement was concluded that allowed the squatters a role as managers of the fortress until the renovation that started in 2008. After the renovation, former squatters were involved in the foundation that assumed responsibility for the fortress. Other conservational squatting projects failed, or partly failed. The houses in the Piersonstraat in Nijmegen were evicted, which caused a riot, although the parking garage was never built.

Conservational squatting also made an impact on neighborhood-wide planning 
conflicts. Wates, writing about the Tolmers Square neighborhood (1976: 81) concludes that "the only effective way of preventing the physical fabric from deteriorating proved to be the squatting of empty buildings." The buildings on Tolmers Square itself did not survive, but surrounding Georgian streets escaped demolition and office construction in the area was less than originally planned. In the Nieuwmarkt neighborhood, squatters could hang on to their buildings on the Zwanenburgwal and Ververstraat, preserving them from demolition. The struggle against a planned motorway through the Nieuwmarkt neighborhood, in conjunction with a subway line underneath, and surrounded by office blocks involved a coalition between elitist conservationists, who were mainly interested in preserving monuments, and anarchist activists who wanted a mixed-use, affordable vibrant neighborhood in which the human scale dominates. The subway line was built as planned but the motorway project was stopped after an activist campaign, which caused prospective developers of office buildings to lose interest. Furthermore, the City made two changes to the plans that were in accordance with the activists' demands that entailed restoring the original street plan. One decision was to place a new housing block at the south side of the Anthoniesbreestraat in such a way, that only a space wide enough for a narrow street remained, precluding an eventual later development as a major traffic artery. This decision was made after a violent confrontation at an attempted demolition in 1974 and following a recommendation made by officials to give in to the demands as a way to prevent further deterioration of the relations (Hoekema, 1978). The second decision was to construct new housing on top of the subway tube, a considerable extra outlay, which was put on the subway construction budget (Mamadouh, 1992).

In 1975, while the squatters were preparing the defenses of the squats on the Rechtboomsloot, which included a hanging and covered bridge across the canal, the City Council revoked an earlier decision to create new subway lines after the one that cut though the Nieuwmarkt.

For the case of Kreuzberg, the project overview of the Internationale Bauaustellung Berlin 1987 (Feye, 1987) lists various buildings, that had been slated for demolition, squatted and finally renovated. Feye (1987: 198) notes that the squatting actions in Kreuzberg prepared the climate for the policy change that occurred in 1981. This change entailed that buildings were no longer stripped from tenants and a switchover was made to a more careful way of urban renewal. Instead of the originally planned demolition of 2200 apartments, only 14 side wings and backhouses were demolished. Successful use of squatting to prevent the conversion of affordable rentals into condominiums occurred in Rotterdam, the Netherlands (Kaulingfreks et al., 2009:12, 94). When the owner of the block Zwaerdecoonstraat/Snellinckstraat had managed to induce half of the tenants to move out and had the insides of the empty apartments demolished, remaining tenants organized squatting by students and artists in an attempt to block gentrification. Squatters who caused disturbance were told to change their behavior or leave. Policy makers found the creative community that developed attractive, which led to the decision to renovate the buildings as affordable rentals. The tenants were able to stay while the squatters had to move on to another neighborhood. Although, as in this case, squatters can clearly fight gentrification, at least since 1981 (Mier and Jansen, 1981), the issue has been raised whether squatters may inadvertently be spearheading gentrification (Pruijt, 2003). Perhaps it would be more correct to say that squatters can be spearheading preservation, which may be a precondition for gentrification. 


\section{Political squatting}

Squatting can be a promising field of action for those who are engaged in antisystemic politics and who identify themselves with revolutionary or "autonomous" ideas. For them, power, in this configuration counter-power vis-à-vis the state, is important. Squatting is not a goal in its own right, it is attractive because of the high potential for confrontations with the state. The label "political squatting" does not imply that I see other forms of squatting projects as a-political, indeed, as Wates (1976: 160) suggested, squatting is generically political. I have chosen this label because here the involvement in squatting is driven by an ulterior anti-systemic political motive. The reason for considering political squatting as a separate configuration is that it has its own logic, which deviates sharply from the logic of the other configurations. A case in point is the Amsterdam squatting group called the "Woongroep Staatsliedenbuurt", that had a strategy that was coherent in itself but that did not fit logically in squatting as an alternative housing strategy, deprivation based squatting, entrepreneurial squatting or conservational squatting. The most salient way in which this group was different was in organizing large-scale squatting of social (low-income) housing allocated by the municipal housing authority. For the other squatters in Amsterdam, this type of housing was off-limits because they felt that squatting was all about adding to the low-income housing stock, not competing for a share of it. Disapproving of the squatting of distributed social housing is consistent with what I described as "squatting as an alternative housing strategy". The "Woongroep Staatsliedenbuurt" also did not fit into the configuration of deprivation based squatting: many participants squatted for themselves, and they lacked the ideology of helping a group that is wrongfully being ignored by the authorities. The Woongroep Staatsliedenbuurt's main justification for squatting allocated low-income housing was, that the municipal housing queue system functioned as a way of pacifying the tens of thousands of home-seekers (Duivenvoorden, 2000: 151). In line with this argument, the municipal housing distribution office was attacked several times; files were destroyed. The idea was that a collapse of the housing queue system would set the scene for a revolt of home-seekers. Thus, in this case, the driver was a political motivation.

Before this, in Germany in the early 1970s there had been a wave of political squatting. Political groups that had part of their roots in the student movement, such as the "K-Gruppen", Leninists known for their internal disputes about the "correct line", and especially "Spontis", representing a more anti-authoritarian strand, launched squatting projects in various cities. This wave started after activists had become disillusioned with an earlier strategy of trying to radicalize workers by taking up blue collar jobs and becoming active within firms. When it became apparent that this strategy was not effective, they decided to focus their attention to the sphere of reproduction, that is to the working class neighborhoods. Most activity was in Hamburg and Frankfurt, cities ruled by social democrats (BetsetzerInnenkongress, 1995). During a radio debate, a Frankfurt activist explained:

"It was about exposing speculation with buildings and land; we wanted to show that the Frankfurt social democrats were exceedingly reformist and to document that the so-called reformists tactically cooperate with financial capital" (Grundmann et al, 1981: 49)

and

"We really thought for some time that it should be possible to widen the housing struggle cycles - the occupations, evictions and mass organization in 
between - beyond the, at most, 5000 or 6000 people that participated, and that this could become an influential factor in changing the political landscape, at least in Frankfurt. I still recall how thrilled we were to read headlines in the Frankfurter Neue Presse like "Dual Power in Frankfurt". And for some moments, we were prepared to believe this; that there is a dual structure of urban power: the formally institutionalized one, and us". (Grundmann et al., 1981: 51).

In 2003, political squatting made a very short come-back in the Netherlands, albeit in a very moderate shape. "Rood" ("Red"), the youth organization of the SP, Socialist Party, positioned at the left side of the social-democratic Partij van de Arbeid, started a campaign of occupations to address the housing shortage for young people, which involved actual squatting.

Especially when compared to squatting as an alternative housing strategy, in political squatting there is a relatively pronounced distinction between leaders and rank-andfile political squatters. Together, political squatters may view themselves as a vanguard, poised to lead a mass into a wide ranging struggle. They see the nonpolitical squatters, i.e. squatters whose projects fit in the other configurations, as potential recruits for this mass to be led.

In Italy in the late 1960s and early 1970s, political groups such as Lotta Continua latched onto the occupations that had started spontaneously (Rising Free, 1973; Welschen, 1996: 82-86). In a later phase, Autonomen became involved, seeking confrontations "even if it did contribute little or nothing to the preservation of occupied houses" (Welschen, 1996: 86).

The Autonomen consisted of different groups that partly fought against each other and partly complemented each other. They tended to join other groups, for example in mass demonstrations and then to take violent action. They refused to comply with the restraint on violent behavior asked for by demonstration organizers. They also tried to obtain hegemony over the entire countermovement (Welschen, 1996).

Welschen (1996: 129-130) points out that Autonomist ideology was rooted in Leninist thought, adapted by Toni Negri and others to the reality that young people were getting less inclined to participate in top-down controlled movements; the ideological leaders thought that concentrating on concrete action practices, instead of building an organization, would lead to a cycle of increasingly severe confrontations with the state. The idea was that such confrontations would, in turn, stimulate centralization of the movement.

In Amsterdam, political squatters developed the strategy of taking over the defense of several buildings whose occupants had lost hope of being able to stave off eviction, and turning these into fortified focal points for confrontations with the state. A high profile example is the Groote Keyser. The political squatters were especially interested in mobilization against the social democratic party that was in control of city politics. Also they worked hard to create stable structures in the squatters' movement, with the ideal of building a coherent, prepared group of disciplined activists who were committed to confronting the state. Many squatters who did not share the ideological background of the political squatters went along with this, led by feelings of solidarity. This course of action seemed attractive because it helped squatters win concessions, and because of the empowerment brought about by stronger organization and the experience of being taken seriously by the local state and the media.

Nevertheless, a cleavage developed in the Amsterdam squatter scene. Squatters who 
saw squatting primarily as an alternative housing strategy or as a basis for entrepreneurial projects increasingly disliked the centralized coordination and the almost paramilitary organization and style that surfaced in confrontations. It started to dawn on them that they had been manipulated by the political squatters.

The political squatters, in turn, grew disappointed: they resented the large number of squatters who, in their view, just acted without a clear political vision, i.e. squatting as an alternative housing strategy, or were only interested in their own small enterprises, i.e. entrepreneurial squatting. A conflict erupted, following a small internal uprising against the leadership of the political squatters, and an attempt by the political squatters' leaders to reconstruct the movement that entailed branding some squatters "traitors".

In terms of framing, the theme of treason seems recurrent. It is a type of accusation that can be directed both at social democrats in city governments as well as against squatters operating in other configurations.

The outcomes of political squatting tended to be disappointing for the participants. The political squatting campaign of the early 1970s in Frankfurt and other German cities ended in evictions, not in the mass mobilization that activists had hoped for. German political squatting did not even leave a legacy that inspired future squatters: the next German squatting wave that started in 1979 followed the pattern of squatting as an alternative housing strategy (Koopmans, 1995: 170).

In Amsterdam, a conflict with other squatters in 1988 forced the political squatters to withdraw from the scene (Adilkno, 1994). This infighting was not just about goals, or ideology or organization structure. It involved various characteristics that together set the configuration of political squatting apart from squatting as an alternative housing strategy and entrepreneurial squatting. Therefore, this internal conflict can be understood as interconfigurational conflict.

In the Berlin squatters' movement, a fissure developed along the dividing line between squatting as an alternative housing strategy and political squatting. Inspired by developments in Italy, part of the squatters began to define themselves as Autonomen. This is the part of the movement that refused to negotiate about legalization. The Autonomen were especially enraged about the repression directed against squatters and criticized the other squatters for only fighting to preserve their own free spaces and not against the system:

"Conquering 'free spaces' and making them secure ... this is classical reformism. That does not destabilize any system - the capitalist system reacts very flexibly: free spaces can be integrated, resistance channeled into ghettos without explosive power: playgrounds" (Geronimo, 1995, quoted in BetsetzerInnenkongress, 1995: 16).

In Amsterdam in 1982 a "Militant Autonomen Front" claimed a light bomb attack on the municipal housing distribution office. This provoked a devastating attack from within the squatters' scene, in which the autonomen were subtly bestowed with ridicule. The protagonists were the editors of the squatters' magazine "Bluf!" ("Bluff!"). An involuntary accessory was Ton van Dijk, a journalist of the mainstream magazine Haagse Post, who was eager to produce a juicy story about emerging terrorism in the Netherlands. The "Bluf!" editors approached him with the offer to arrange, in return for money, an exclusive interview with the Militant Autonomen Front. Ton van Dijk was blindfolded, taken to a "secret location", and given the opportunity to interview three masked "members of the Militant Autonomen Front". 
This role was played by the Bluf! editors themselves, who had prepared for the interview by memorizing an extensive array of revolutionary clichés. The Haagse Post published the nonsensical interview as its cover story, showing the photograph of the brave journalist in the company of the three masked men, that was supplied as part of the interview deal. Bluf!, in turn, published a picture of the blindfolded journalist surrounded by the three grinning Bluf! editors (Kommando GIRAF, 1982).

\section{Concluding notes}

The root cause of diversity in squatting is that those initiating squatting projects have varying goals. In the typology developed in this paper, there is no type of squatting that has subcultural expression as its goal. This is because of the importance of the need for space for all squatters, including those engaged in subcultural expression. Instead, there is the configuration "squatting as an alternative housing strategy" where the goal is to house oneself, and in which there is a two-way relation between squatting and countercultural expression: the opportunities for countercultural expression are a bonus that adds to the attractiveness of squatting, and once someone is settled in a squat, she of he will find an environment that is, to so some extent, conducive to a countercultural development. Thus, I argue against making subculture the central point in our understanding of squatting.

Neither does ideology seem to be a good starting point for an analysis of squatting. In squatting, ideology is loosely coupled to practice. Seeing it as loosely coupled is a way to avoid tripping over some paradoxes, such as between the belief espoused by squatters that "the squatters' movement is dominated by a great repulsion against hierarchical order, authority, planning and pressure" (Wietsma, Vonk and van den Burght, 1982: 134) and the existence of hierarchical order, authority, planning and pressure, several examples of which have presented in the pages above.

For all configurations, there were solid examples that show that they can be viable. Of the two configurations in which housing is most central, deprivation based squatting and squatting as an alternative housing strategy, the latter seems to have everything going for it. It is open to everyone, regardless of social class, it is interesting for resourceful activists but can simultaneously offer a haven for vulnerable people. It allows a wide range of skills to be exercised, empowers and produces fun instead of a display of misery.

This leads to the question: why does deprivation based squatting exist at all? The analysis presented above suggests that this is because of legitimacy. Squatting is a breach of property rights, and thereby likely to provoke negative reactions. The breach of property rights can be easier to swallow when it involves housing needy people in buildings that belong to owners that a have a moral obligation to house the needy. Deprivation based squatting offers this opportunity.

Self-help, as in squatting as an alternative housing strategy, can be an extra a tax on tolerance. In squatting as an alternative housing strategy, this effect can be mitigated by targeting houses or buildings that are either too much in disrepair or too sumptuous to be let as affordable housing. This can logically deflect accusations of queuejumping. The extra tax on tolerance caused by self help is not present in deprivation based squatting, at least in cases where it is clearly organized to help other people. Thus, the level of tolerance is a situational factor, to borrow a term from Mintzberg's (1983) contingency theory, with deprivation based squatting fitting a low level of tolerance. The UK squatting history suggests that deprivation based squatting paved the way for squatting as an alternative housing strategy.

Entrepreneurial squatting, in as far as it involves providing a service to the 
community, can deflect attempts to portray squatters as usurpers, in addition to the effect already produced by targeting unwanted buildings or buildings that have at least been empty for long times. A deprivation based squatting project can be incorporated as a separate division in an entrepreneurial squatting project.

Squatting as an alternative housing strategy and entrepreneurial squatting, once some legitimacy has been established, could go on forever, unless there is a very efficient repression or all potential opportunities are destroyed by an effective "anti-squatting" industry, i.e. firms that supply the minimum number of tenants on contracts that offer no security, from being squatted.

The fairly common idea that movements inevitably have a life cycle does not seem to apply to squatting as an alternative housing strategy and entrepreneurial squatting. Tarrow (1994) describes a life cycle dynamic that involves the increased use of violent means and militant rhetoric to motivate core participants and continue to get public, media and state attention, while this in turn causes supporters to walk away. Such an escalation can occur in the resistance against evictions, but this does not have to affect the squatting of new buildings. Van Noort (1988) observes that squatters in Amsterdam had become trapped in a dynamic of radicalization causing them to lose all attractiveness, however, in contrast to his assessment, squatting continued. In terms of the configurations, it was political squatting that was subject to a radicalization dynamic, leaving squatting as an alternative housing strategy and entrepreneurial squatting unaffected.

Castells (1983: 328) suggests that the inevitable fate of urban movements is institutionalization leading to identity loss, while Kriesi, H., R. Koopmans, et al., (1995) describe protest as occurring in waves, in which institutionalization is the phase between protest and reform. Mamadouh (1992) shows how city planners coopted the views promoted by squatters; however her conclusion that this was the end of the squatters' era proved to be unwarranted. Conservational squatting was affected, not the squatting as an alternative housing strategy nor entrepreneurial squatting. Plus, conservational squatting later resurfaced in the form of resistance to gentrification. That squatting as an alternative housing strategy and entrepreneurial squatting do not seem to have a life cycle dynamics can help explain why squatting can be persistent over time.

Squatting is, along with rent strikes and the developments of alternative spatial plans, one of the few action repertoire items that are specific to urban movements. Urban movements can be seen as aimed at realizing collective consumption demands within a framework of promoting the city as a use value against commodification (Castells, 1983). Squatting has the unique property of combining self help with demonstrating an alternative and with a potential for protest. The various configurations point to different possibilities. Deprivation based squatting addresses problems in the provision of social housing, while conservational squatting asserts a vision of a city in which citizens are not spatially sorted our according to income, functions are integrated and a small-scale urban fabric maintained. Squatting as an alternative housing strategy can address exclusion on the housing market, for example of young people, or a housing shortage in general, but it can simultaneously demonstrate the use value of buildings, blocks or neighborhoods that planners slated for demolition, or develop into a protest against real estate speculation. In as far as promoting squatting as an end in itself is part of the movement's identity, it offers a barrier against cooptation. Entrepreneurial squatting can be a means to advance cultural demands. Examples are venues for pop music that were originally created by squatting. Finally, political squatting can increase the level of disruptiveness that the other types of 
squatting already potentially have, but it carries the risk of triggering internal conflict and a repressive backlash.

\section{Acknowledgements}

I wish to thank the anonymous referees, colleagues at Erasmus University, Bart van der Steen and members of the Squatting in Europe research network for their stimulating comments on earlier versions. I am also grateful to all the squatters who took the time to explain their projects to me. The usual disclaimer applies.

\section{References}

Adilkno 1994. Cracking the Movement. Squatting Beyond the Media. New York: Autonomedia.

Aktiegroep Nieuwmarkt (1977). Bouwen voor de buurt? Amsterdam.

Anon. 1998. De stad was van ons. 28 vraaggesprekken met krakers en kraaksters. Uitgeverij Snotneus, Amsterdam.

ASS (1996) Squatters Handbook, 10th edition. Advisory Service for Squatters, London

Azzellini, D. (2002) Interview mit Tute Bianche. In D. Azzellini (ed.), "Genиa".

Italien, Geschichte, Perspektiven. Assoziation A Verlag, Berlin.

Bailey, R. (1973) The Squatters. Penguin, Harmondsworth.

Benford, R. D. (2000) Framing Processes and Social Movements: An Overview and Assessment. Annual Review of Sociology 26.1, 611-639.

Berg, T. v. d. (2007). Van kerk tot café. Speciale uitgave ter gelegenheid van de officiële opening van 'Olivier' op 28 januari 2007. Debuut, Utrecht. URL

http://utrecht.cafe-olivier.be/files/utrecht.cafe-olivier.be/vankerktotcafe.pdf (accessed on 25 February 2010).

BesetzerInnenkongress (1995) Reader zum bundesweiten BesetzerInnenkongress von 12.-14 Mai in Leipzig. Conne Island, Leipzig.

Bijlsma, A., R. Brouwers, D. Oosterbaan and D. Schuiling (1974) De ontwikkelaar heeft vrij spel! Wonen TA/BK 2.19, 1-32.

Birke, P. and C. Holmsted Larsen (eds.) (2007) Besetze deine Stadt! - BZ din by!

Häuserkämpfe und Stadtentwicklung in Kopenhagen. Assoziation A, Berlin.

Birke, P. (2009) Van 'Fünffingerplan' tot 'Bambule. Stedelijke Politiek, Kraken en de strijd om leefruimte in Duitse steden van ' 1968 ' tot $\mathrm{Nu}$. In L. van Hoogenhuijze, J.

Lukkezen, A. Petterson and B. van der Steen (eds.) Kritiek. Jaarboek voor socialistische discussie en analyse 2009. Aksant, Amsterdam.

Bosma, J. H. Bijnen, S. Davidson, J. Eissens, K. van Harn and T. Nijenhuis (1984) De beste aktiegroep ter wereld. 40 dorpsverhalen uit de Nieuwmarkt. Stichting Uitgeverij de Oude Stad, Amsterdam.

Breek, P. and F. de Graad (2001) Laat duizend vrijplaatsen bloeien. onderzoek naar vrijplaatsen in Amsterdam. De Vrije Ruimte, Amsterdam.

Bussemaker, J. (1986) De fatsoenering van het avontuur. Marge magazine 10.1, 6-11. Bruls, A. (2006). De Pierson. Verhalen over een volksopstand in twintigste-eeuws Nijmegen. De Stratemakerstoren, Nijmegen.

Calhoun, C. (1993) New social movements of the early nineteenth century. Social Science History 17.3, 385-427.

Castells, M. (1983). The city and the grassroots : a cross-cultural theory of urban social movements. Edward Arnold, London. 
Clarke, J., S. Hall, T. Jefferson and B. Roberts (1976) Subcultures, cultures and class. In S. Hall and T. Jefferson (eds.) Resistance Through Rituals. Youth Subcultures in Post-war Britain. Hutchinson, London.

Consorzio Aaster (1996) Polisemia di un Luogo. In E. Guarneri (ed.) Centri Sociali: Geografie del Desiderio. Dati, Statistiche, Progetti, Mappe, Divenire. Shake, Milano. Corr, A. (1999) No Trespassing. Squatting, Rent Strikes and Land Struggles Worldwide. South End Press, Cambridge MA.

Della Porta, D. and D. Rucht (1995) Left-Libertarian Movements in Context: A Comparison of Italy and West Germany, 1965-1990. In C. J. Jenkins and B. Klandermans (eds.) The Politics of Social Protest. Comparative Perspectives on States and Social Movements. UCL Press, London.

Draaisma, J. and P. van Hoogstraten (1983) The Squatter Movement in Amsterdam. International Journal of Urban and Regional Research 7.3, 405-416.

Duivenvoorden, E. (2000) Een voet tussen de deur. Geschiedenis van de kraakbeweging 1964-1999. Arbeiderspers, Amsterdam.

Fekete, L. (1998) Bologna Immigrant Squatters Movement Wins Public Support, Independent Race and Refugee News Network. URL http://www.irr.org.uk (accessed on 18 March 2010).

Feye, C. (ed.) (1987) Internationale Bauausstellung Berlin 1987. Projektübersicht. Bauausstellung Berlin $\mathrm{GmbH}$, Berlin.

Florida, R. (2002) The Rise of the Creative Class. And How it's Transforming Work, Leisure, Community and Everyday Life. Basic Books, New York.

Friend, A. (1980) The Post War Squatters. In N. Wates and C. Wolmar (eds.)

Squatting. The real story. Bay Leaf Books, London.

Geronimo (1995) Feuer und Flamme. Zur Geschichte der Autonomen. Edition IDArchiv, Berlin.

Grundmann, G., C. Schulz, W. Becker, J. Emig and A. Pospisil (1981) Sachschaden. Häuser und andere Kämpfe. Verlag "die Tageszeitung", Frankfurt.

Hinton, J. (1988) Self-help and Socialism. The Squatters' Movement of 1946. History Workshop Journal 25.1: 100-126.

Holm, Andrej and Armin Kuhn (2011) Squatting and Urban Renewal: The Interaction of Squatter Movements and Strategies of Urban Restructuring in Berlin. International Journal of Urban and Regional Research 35.3, 477-689.

Johnstone, C. (2000) Housing and Class Struggles in Post-war Glasgow. In M. Lavalette and G. Mooney (eds.) Class Struggle and Social Welfare. Routledge, London.

Kallenberg, F. (2001) Desire is Speaking. Utopian Rhizomes. In S. Poldervaart, H. Jansen and B. Kesler (eds.) Contemporary Utopian Struggles. Communities Between Modernism and Postmodernism. Aksant, Amsterdam.

Katsiaficas, G. (1997) The Subversion of Politics: European Autonomous Social Movements and the Decolonization of Everyday Life. Humanities Press, Atlantic Highlands, New Jersey.

Katz, S. and M. Mayer (1985) Gimme Shelter: Self-Help Housing Struggles Within and Against the State in New York City and West Berlin. International Journal of Urban and Regional Research 9.1, 15-47.

Kaulingfreks, F., T. Combrink, I. Schrauwen, G. Egas, J. Cafard, P. Rensen, J. W. Wieland, M. van Ouwerkerk, D. Schmidt, D. Hallegraeff, M. Oudenampsen, V. Feith, L. van der Velden, B. Rosinga and P. Bouwknecht (2009) Witboek kraken. Krakend nederland presenteert: 132 bladzijden met meer dan 80 kraakpanden in 20 steden. De Papieren Tijger, Breda. 
Kinghan, M. (1977) Squatters in London. Institute of Community Studies / Shelter. National Campaign for the Homeless, London.

Klein, N. (2001) Squatters in White Overalls. The Guardian, Friday June 8, URL http://www.guardian.co.uk/world/2001/jun/08/globalisation.comment?INTCMP=SRC H (accessed on 4 July 2011).

Kommando GIRAF. 1982. De ontmaskering. Wie is hier nou maf? Bluf! 2(31), 19 August, 1,4-5.

Koopmans, R. (1995) Democracy from Below. New Social Movements and the Political System in West Germany. Westview Press, Boulder.

Kriesi, H., R. Koopmans, J. W. Duyvendak and M. G. Guigni (1995) New Social Movements in Western Europe. A Comparative Analysis. UCL Press, London.

Loo, H. v. d., E. Snel and B. van Steenbergen (1984). Een wenkend perspectief Nieuwe sociale bewegingen en culturele veranderingen. De Horstink, Amersfoort. Lowe, S. (1986) Urban Social Movements. The City After Castells. St. Martin's Press, New York.

Maffeis, S. (2002) Interview mit Roberto Bui. In D. Azzellini (ed.) "Genua". Italien, Geschichte, Perspektiven. Assoziation A Verlag, Berlin.

Maggio, M. (1998) Urban Movements in Italy: The Struggle for Sociality and Communication. In R. Wolff, A. Schneider, C. Schmid, P. Klaus, A. Hofer and H. Hitz (eds.) Possible Urban Worlds: Urban Strategies at the End of the 20th Century. Birkhaüser, Basel.

Malyon, T. (1998) Tossed in the Fire and they Never Got Burned: the Exodus Collective. In G. McKay (ed.) DiY Culture. Party \& Protest in Nineties Britain. Verso, London.

Mamadouh, V. (1992) De stad in eigen hand. Provo's, kabouters en krakers als stedelijke sociale beweging. SUA, Amsterdam.

Marco (2000) Radicaal links in Nederland sluit zich op in de marge. Ravage 5(1), 14. Martínez, M. (2007) The Squatters' Movement: Urban Counter-Culture and AlterGlobalization Dynamics. South European Society and Politics 12(3), 379-398. McKay, G. (1998) DiY Culture: Notes Towards an Intro. In Pp. 1-53 in G. McKay (ed.) DiY Culture. Party \& Protest in Nineties Britain. Verso, London.

Melucci, A. (1989). Nomads of the present: social movements and individual needs in contemporary society. Hutchinson Radius, London.

Mintzberg, H. (1983) Structure in Fives: Designing Effective Organizations. Prentice Hall, Englewood Cliffs.

Membretti, A. (2007) Centro Sociale Leoncavallo. Building Citizenship as an Innovative Service. European Urban and Regional Studies 14.3, 255-266 Mier, N. and P. Jansen (1981). Daar komen de krakers, paper Sociology of the Built Environment, University of Amsterdam: Amsterdam.

Moan, P. (1980) Learning to Learn. In N. Wates and C. Wolmar (eds.) Squatting. The Real Story. Bay Leaf Books, London.

Mudu, P. (2004) Resisting and Challenging Neoliberalism: The Development of Italian Social Centers."Antipode 36.5, 917-941.

Nepstad, Sharon Erickson (1997) The Process of Cognitive Liberation: Cultural Synapses, Links, and Frame Contradictions in the U.S.-Central America Peace Movement. Sociological Inquiry 67.4, 470-487.

Ooststroom, F. W. van (2010). Cultuurhistorische waardestelling boerderij Bergse Linker Rottekade 451, 3069 LV Rotterdam. Stad en Streek Cultuurhistorie, Vlaardingen.

Pettitt, A. (1980) Better than the Telly Any Day. Outwitting a Private Landlord in 
London's East End - Myrdle and Parfett Streets. In N. Wates and C. Wolmar (eds.) Squatting. The Real Story. Bay Leaf Books, London.

Pichardo, N. A. (1997) New Social Movements: A Critical Review. Annual Review of Sociology 23.1, 411-430.

Platt, S. (1980) A Decade of Squatting. The Story of Squatting in Britain Since 1968.

In N. Wates and C. Wolmar (eds.) Squatting. The Real Story. Bay Leaf Books,

London.

Polletta, F. and J. M. Jasper (2001) Collective identity and social movements. Annual Review of Sociology 27.1, 283-305.

Priemus, H. (1983) Squatters in Amsterdam: Urban Social Movement, Urban

Managers or Something Else? International Journal of Urban and Regional Research 7.3, 417-427.

Pruijt, H. (2003). Is the Institutionalization of Urban Movements Inevitable? A Comparison of the Opportunities for Sustained Squatting in New York City and Amsterdam. International Journal of Urban and Regional Research 27.1, 133-157. Pruijt, H. (2004) Squatters in the Creative City: Rejoinder to Justus Uitermark. International Journal of Urban and Regional Research 28.1, 699-705.

Rising Free (1973) Take over the City. Community Struggle in Italy. Rising Free, London.

Romano, A. (1998). Possibilities for Liberating Everyday Life. In R. Wolff, A. Schneider, C. Schmid, P. Klaus, A. Hofer and H. Hitz (eds.) Possible Urban Worlds: Urban Strategies at the End of the 20th Century. Birkhaüser, Basel.

Ruggiero, V. (2000) New Social Movements and the 'Centri Sociali' in Milan. Sociological Review 48.3, 167-185.

Tarrow S. (1994) Power in movement, Social Movements and contentious politics. Cambridge University Press, Cambridge.

Uitermark, J. (2004) The Co-optation of Squatters in Amsterdam and the Emergence of a Movement Meritocracy: A Critical Reply to Pruijt. International Journal of Urban and Regional Research 28.1, 687-698.

Van der Pennen, T., A. Bertram, L. de Boer and I. vanVliet (1983) Kraken en volkshuisvesting. R.O.V., Leiden.

Van der Raad, J. W. (1981) Kraken in Amsterdam. Amsterdam: Roelof

Kellerstichting.

Van Diepen, M. and A. de Bruijn-Muller (1977) Kraakakties in Gliphoeve. Sociale chaos als voorwaarde voor kapitalistiese ontwikkeling. Zone 2.4, 27-44.

Van Gemert, F., D. Siegel, R. Visser, D. Dadusc and C. Brouwers (2009) Kraken in Amsterdam anno 2009, Sectie Criminologie, Vrije Universiteit Amsterdam, Amsterdam.

Van Noort, W. (1988) Bevlogen bewegingen. Een vergelijking van de antikernenergie, kraak- en milieubeweging. SUA, Amsterdam.

Van Tijen, Tjebbe (2008). Zwartmakers en een pleidooi voor een "Witboek Kraken." Retrieved November 4, 2008

(http://imaginarymuseum.org/LimpingMessenger/WitboekKraken2008.html)

Visser, A. (2006). Ontruiming Fort Pannerden. PROMOTOR. Contactorgaan van de vereniging van genie onderofficieren. 30. 114, 8-9.

Wakefield, S and Grrrt (1995) Not for rent. Conversations with Creative Activists in the UK. Evil Twin Publications, Amsterdam.

Wates, Nick. 1980. "Introducing squatting." In N. Wates and C. Wolmar (eds.) Squatting. The Real Story. Bay Leaf Books, London.

Wakeren, B. van (1998). The poldermodel nader bekeken. Een zoektocht naar directe 
milieuactie. Ravage. 273/274. URL: http://www.ravagedigitaal.org (accessed on 23 February 2011).

Wates, N. and C. Wolmar (eds.) (1980) Squatting. The Real Story. London: Bay Leaf Books.

Welschen, T. (1996) Het Italiaanse complex. Partijen en bewegingen van 1970 tot 1990. Uitgeverij THOTH, Bussum.

Wietsma, A., J. Vonk and F. van der Burght (1982). Als je leven je lief is.

Vraaggesprekken met krakers en kraaksters. Lont, Amsterdam.

Wright, S. (2000) 'A Love Born of Hate' - Autonomist Rap in Italy. Theory Culture \& Society 17.3, 117-135.

Ziere, P. (1992) Laat het duidelijk zijn: neem helm, stok en molotovs mee! De ontwikkeling van de kraakbeweging tot radicale beweging. In: J.W. Duyvendak, H. A. van der Heijden, R. Koopmans and L. Wijmans (eds.) Tussen verbeelding en macht. 25 jaar nieuwe sociale bewegingen in Nederland, SUA, Amsterdam.

\footnotetext{
${ }^{1}$ With "relatively long term use" is meant that the squatting action is intended to make relatively long term use possible, which is not necessarily by the same people. In fact, in some squats inhabitants and users come and go in rapid succession.

${ }^{2}$ Apart from pregnant women, old and sick people.

${ }^{3}$ Some accounts of this squatting wave emphasize self- organization (Friend 1980), other accounts stress the leadership by cadres of the Communist Party (Hinton 1988).

${ }^{4}$ I would count poor people living unspectacularly and hidden in a squat as squatting as an alternative housing strategy, unless it has been organized for them by militants. If militants organized it for them, it would be deprivation based squatting.

${ }^{5} \mathrm{I}$ inserted this question in an online questionnaire for the CentERpanel of CentERdata, as part of the project Arbeid, Bedrijf en Sociale Zekerheid in Nederland 2006. The CentERpanel is an appropriate representation of the Dutch-speaking population.

${ }^{6}$ Vrankrijk was closed by the Municipality in 2009 in the aftermath of a 2008 violent incident between members of the bar group and two intoxicated visitors, that left one visitor disabled. The collective was accused of obstructing the police investigation.

${ }^{7}$ Occasionally, long established residents, who may be more working class, can squat as well. Not for their housing, because the already live in the area, but to create a meeting space for neighborhood action (Amsterdam, Bickerseiland), also their children can start squatting (Amsterdam,

Nieuwmarktbuurt).

${ }^{8}$ Alongside other actions such as spreading information in the neighborhood about the plan, organizing a neighborhood-dwellers group, supplying the media with information while attracting the attention of journalists by (playful)protest, naming and shaming of property developers, establishing legal protection for the neighborhood using the opportunities provided by planning laws, trying to prevent the construction of new roads that would provide increased accessibility of the make the neighborhood interesting for property developers, sharing information with other neighborhood groups, and taking disruptive action.
} 